\title{
Violent, political, and administrative repression of the Chinese minority in Indonesia, 1945-1998
}

\author{
MARY SOMERS HEIDHUES
}

\begin{abstract}
Since Indonesian independence, its Chinese minority has been a victim of violent outbreaks, but also of restrictive policies arising from politics and administrative measures. From about 1957, with the closure of Chinese-language schools and subsequent regulations about expression of Chinese culture, many speak of the "erasure" of that culture through such restrictions. Violent anti-Chinese outbreaks have proceeded from the Indonesian Revolution and the presidency of Soekarno (especially the so-called "PP-10" measures against Chinese rural traders) to the era of Suharto, which began with the 1965-1967 anti-Communist massacres and their effects on ehtnic Chinese and came to an end with the provocation of violence against ethnic Chinese in major Indonesian cities. This paper also discusses the reactions to these waves of anti-Chinese measures: rejection, flight, but also countermeasures in the form of political activity. In the years since Reformasi, as attacks on them have subsided, many Chinese Indonesians have chosen to emphasize their participation in Indonesian history and their positive contributions to Indonesian culture.
\end{abstract}

KEYWORDS

Indonesia; Chinese Indonesians; violence; culture.

MARY SOMERS HEIDHUES has taught in universities in the USA and in Germany. She is author of books and articles about Southeast Asia and especially about the Indonesian Chinese, most recently, "Bangka in the 1950s; Indonesian Authority and Chinese Reality" to be published in Indonesia 103 (April 2017). Mary Somers Heidhues can be contacted at: mheidhues@arcor.de. 


\section{INTRODUCTION $^{1}$}

In a striking installation from the year 2013, called "Ranjang Hujan" (raining bed), Chinese-Indonesian artist FX Harsono displays a canopied Chinese Peranakan bed, perhaps a wedding bed, drenched by water falling from above. A text appears on a display behind the installation, saying in Indonesian, "Dalam tidur kuurai masa lalu, di ujung pena sejarah direka, di ujung senapan sejarah ditipu, di ujung pancuran sejarah tersapu" (In my sleep I entangled the past, at the tip of the pen history is predicted, at the tip of the gun history is deceived, at the end of the fountain, history washed away). ${ }^{2}$ For the artist, this "washing away" is the decades-long erasure of Chinese culture and Chinese heritage in Indonesia, especially between 1965 and 1998, and the erasure of the memory of violent acts against the Chinese minority, beginning with those during the Indonesian Revolution.

FX Harsono is an insider who has shown his work in Indonesia and abroad. My viewpoint is that of an outsider, and the following is a brief account of what a historian may think about such erasures. It will address the reactions of the minority, as far as we can know them, that followed violent outbreaks or repression.

\section{The IndONESIAN ReVOLUTION, 1945-194933}

During the Republican forces' evacuation of Bandung in March 1946, and especially during the so-called First and Second Police Actions, that is the Dutch attacks on the Republic in July 1947 and December 1948, the Republican side repeatedly adopted a tactic of withdrawing before the better-armed British or Dutch attackers, evacuating the population, and executing scorched earth (bumi hangus) - preventing the much stronger enemy from profiting from its conquest. ${ }^{4}$ This meant destroying factories, sugar mills, and much more. Where possible, guerillas continued to attack Dutch lines from the countryside to which they had withdrawn. Evacuation and scorched earth meant burning Chinese property, forcing Chinese to move to other areas, even holding them in makeshift prisons. Some were killed outright and buried in shallow graves. In all, several thousand Chinese were killed in revolutionary violence, perhaps tens of thousands. Property losses were extensive. The violence and loss of life was worse in Sumatra than in Java, but comparatively little is known about anti-Chinese activities there. ${ }^{5}$

1 This is a revised version of a talk for the Chinese Indonesian Heritage Center, Leiden, Netherlands, "Publieksdag", 24 June 2016 (see http://www.cihc.nl/uploads/images/ page_images/Publieksdag_2016_presentatie_Mary_Somers-Chinese_Minority_in_ Indonesia_1945-1998.pdf).

2 For a discussion of this installation and the intention of the artist, see Smith (2015).

3 For a more extended discussion of this period, see Heidhues (2012).

4 This was not a new idea. The Dutch themselves had carried out scorched earth when they retreated before the Japanese attack in 1942. Economically valuable installations, mines and their machinery for example, were systematically destroyed. Republican forces, however, often destroyed "softer" targets, such as homes or shops.

5 Violence against Chinese in Medan provoked the foundation of a Chinese security force 
From the first days after the Japanese surrender and the Proclamation of Independence, Chinese were victims of plunder, robbery, and sometimes kidnapping, but gradually, with the restoration of order in the major cities, these ceased. After that, violence usually took place along the lines of combat.

Among the anti-Chinese attacks during the Revolution, that of Tangerang is the best known because it happened practically on the outskirts of Jakarta and the capital's press reported extensively about it. Many Chinese had settled in rural areas around Old Batavia in early VOC times, and several thousand remained in the twentieth century. In May 1946, Dutch forces attacked and occupied the town of Tangerang, and Republican army forces withdrew from the town and its surrounding region. Irregular troops - laskar - remained behind in rural areas, encouraging violence against Chinese villagers, burning their houses, murdering some, forcibly circumcising men and sometimes raping women. Of an estimated Chinese population of 25,000, over 1000 were dead, over 200 missing, and 15,300 refugees, overwhelmingly Chinese, fled to the city of Jakarta. ${ }^{6}$

What was the position of the Chinese and why were they targeted? To put it most simply, during the Revolution, most Chinese thought of themselves as neutrals and non-combatants, but neutrality was impossible. In addition, ethnic Chinese had the most to lose, their property was burned, and when they were evacuated from towns, they could not find refuge in villages, as did some others. Some Chinese favored the revolution and actively tried to help its cause, $^{7}$ but some also became discouraged because of attacks on Chinese like those in Tangerang and ceased supporting the Republic. Some businessmen were active in helping the Republic acquire supplies and weapons from abroad, participating in a lively smuggling trade with Singapore. ${ }^{8}$ Most tried to survive. Thousands sought refuge in Dutch-controlled areas, leaving the impression that they sided with the Dutch. For security reasons, many did.

Documents in the libraries and archives witness the atrocities perpetrated on Chinese during the Revolution, and there is no need to catalog them here. The Chinese Associations in major cities on Java kept records and even lodged an official protest with the United Nations. Eyewitness depositions and grisly photographs of such atrocities can be found at the Cornell University Library, for example, deposited by a former Dutch journalist, ${ }^{9}$ but Dutch forces, too, were responsible for violence.

there, see Van der Veer (2013). For a compelling account of the Revolution, and especially the hardships of evacuation of civilians, in Karo Batak areas of North Sumatra, see Steedly (2013). The evacuees she describes were village people, not ethnic Chinese, and they seem to have acquiesced in evacuation because they felt it supported the Revolution.

Heidhues (2012: 386-387), citing reports compiled by Chinese community organizations.

Among them were Siauw Giok Tjhan and the later Admiral John Lie.

Twang Peck Yang (1998: 266 ff).

See "Guide to the Niels A. Douwes Dekker Papers", Collection Number: 3480, Division of Rare and Manuscript Collections, Cornell University Library, (http://rmc.library.cornell.edu/ EAD/htmldocs/RMM03480.html). 
My impression from reading documents from this period in the colonial archives - and I cannot prove it - is that the returning Dutch authorities were eager to record atrocities against Chinese because they hoped to keep the Chinese minority from supporting the Republic, while they seldom kept records of losses among ethnic Indonesians. Yet Indonesian military and civilian losses, from violence, forced evacuation, hunger, and preventable disease, went into the tens, perhaps hundreds of thousands. An estimated 8000 to 12,000 Indonesians perished in just three weeks in the November 1945 battle of Surabaya alone, and probably others died when they left Surabaya to take refuge in the countryside. Also in the first weeks of the Revolution, a "brief genocide", as Robert Cribb calls it, brought the death of a comparatively large proportion of Eurasians. ${ }^{10}$

\section{RESPONSES TO VIOLENCE}

Protests directed to the Indonesian and Dutch authorities were to no avail. The ethnic Chinese had to respond in other ways, above all, by movement from the countryside to cities for safety and from contested areas to those controlled by the Dutch. Emigration abroad was limited by the difficulty of finding a safe and open destination - a few students left for China or the Netherlands, but conditions in China were not conducive to taking on immigrants and countries like the USA or Australia were still closed to immigration of Chinese.

Second, many thousands rejected Indonesian citizenship. Between December 1949 and December 1951, Chinese born in Indonesia who had been Netherlands subjects (about $60 \%$ of all Chinese) could automatically become Indonesian citizens or, if they chose, could actively reject Indonesian citizenship and become Chinese citizens. The Indonesian government thought that about ten percent might declare for Chinese citizenship, but when the tally was finally made in 1953 , up to $40 \%$ of those eligible, between 600,000 and 700,000 persons, had officially rejected Indonesian citizenship. When added to the foreign-born (and their children), who were already Chinese citizens, this meant that over half of Chinese in Indonesia were aliens, a surprisingly high number for a young country to absorb. ${ }^{11}$ (In Chinese law, all persons of Chinese descent in Indonesia were still Chinese citizens, something that ended only with implementation of the Dual Nationality Treaty after 1959, as described below.) A small number of Chinese also opted to be Dutch citizens. Among the reasons for rejecting being "Indonesian", although not the only one, was the experience of anti-Chinese violence.

A third reaction was silence. Although the Tangerang incident was wellpublicized because of its closeness to Jakarta, a veil of silence covered most other incidents for years. Journalist Kwee Thiam Tjing wrote a graphic memoir of anti-Chinese violence in Malang, Indonesia dalam api dan bara, published in 1947, which soon vanished from bookshops. It was only republished in $2004 .{ }^{12}$

\footnotetext{
Cribb 2008.

11 Mozingo (1976: 97), citing an official of the Indonesian Department of Justice.

12 Tjamboek Berdoeri 2004.
} 
Some twenty years ago, Claudine Salmon described how the inscription in a cemetery in Bagor, near Nganjuk (Picture 1), avoided a direct description of Revolutionary violence against Chinese.

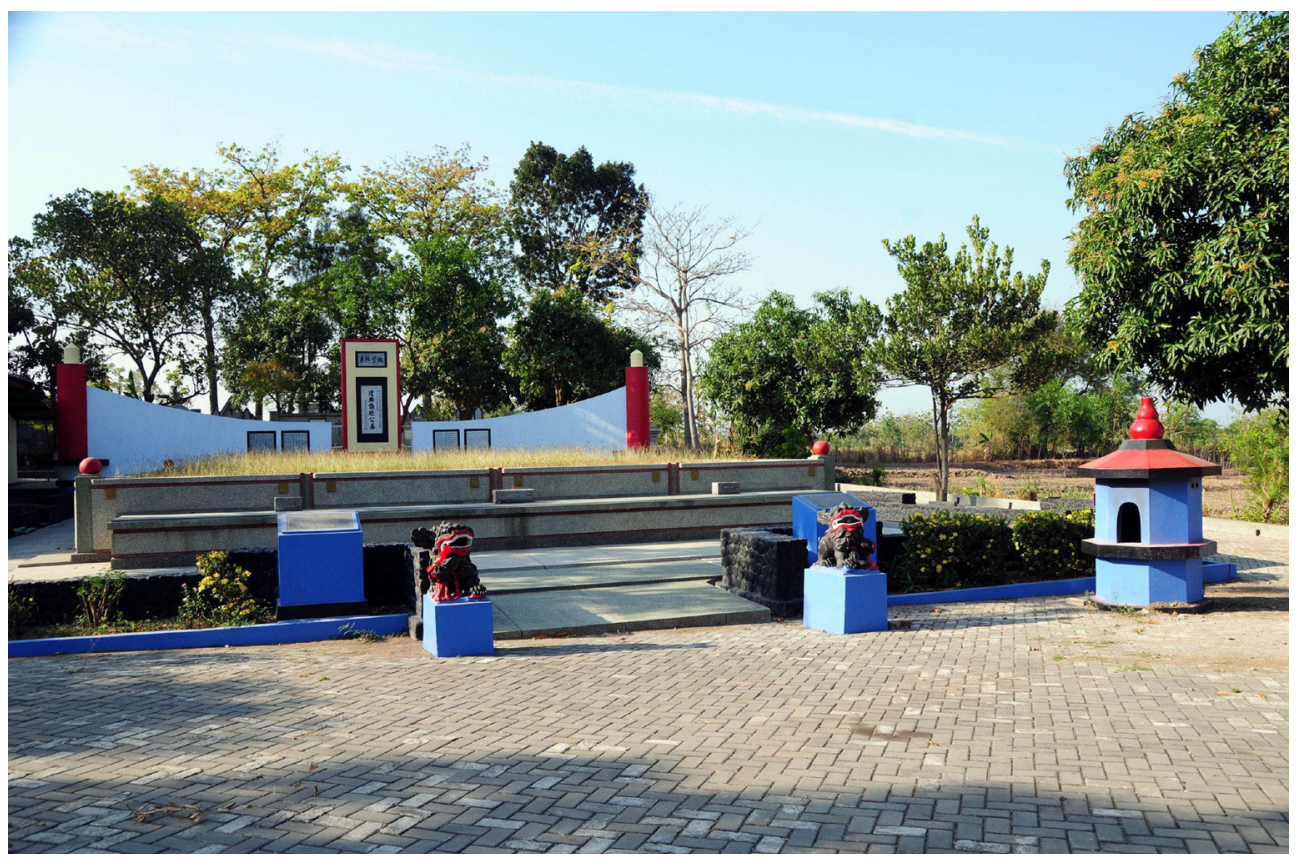

Picture 1. Nganjuk memorial (photograph by FX Harsono, 2012).

This impressive memorial in East Java, not far from Madiun, commemorates some 800 persons killed near there in December 1948. When Dutch forces approached the town during the Second Police Action, the Republican military commander gathered all the male Chinese in the town into a warehouse and set fire to it. Anyone who tried to flee was shot. Siauw Giok Tjhan in his memoirs describes this "cruel" and "ruthless" massacre that left Nganjuk a "city of widows". The memorial was erected in 1951-1952, but it does not explain how these people died. Salmon in her collection of Chinese epigraphy in Java translates the central inscriptions as "Collective Tomb of Our Compatriots Who Met with Difficulty (or Who Were Victims)" and "The remains of 790 compatriots who were victims on the occasion of the Second Dutch Military Action that took place in 1948 are buried here". ${ }^{13}$ Only in 1981 was Siauw's account published, blaming the Republican forces. ${ }^{14}$

Fourth, the name Siauw Giok Tjhan of course also stands for a different response - joining Indonesian politics. After Chinese Indonesians made some false starts in founding political groupings to represent their interests, in March 1954 Siauw joined with other Chinese Indonesians to found Baperki (Badan Permusyawaratan Kewarganegaraan Indonesia). Baperki called itself

13 Salmon and Siu (1997: 740-741).

14 Siauw Giok Tjhan (1981: 142-143). 
the Consultative Body (technically it was not a political party) for Indonesian citizenship. Citizen (WNI, Warga Negara Indonesia), however, usually simply meant "Chinese", even when Baperki denied that it was an organization specifically for Chinese.

\section{The SOEKARNO ERA, 1950-1965}

Some people believe that Chinese Indonesians were protected under President Soekarno, but this is not necessarily true. In reality, political and administrative measures constantly attacked their interests or limited their freedoms. In the 1950s leading political parties attempted to dismantle what nationalists called the "colonial economy" by limiting Chinese businesses and promoting indigenous entrepreneurs. Citizenship also remained a problem. Even the expression "Chinese problem (later: masalah Tionghoa/Cina)" dates at least from the 1950s. ${ }^{15}$

After 1957, the President shared power with the military and the Communist Party. When regional rebellions against Jakarta broke out, martial law put entire regions under military authority, which again had consequences for the Chinese minority. In 1959, the Minister of Trade determined to forbid aliens (meaning "Chinese") from engaging in retail trade outside of about 140 major cities, ${ }^{16}$ something that would limit or abolish their role in rural crop-buying and lending. Some local military commanders then expanded the regulation to require all aliens in their provinces to leave these areas, a regulation that was brutally implemented in West Java, forcing many families to flee to Jakarta or other cities.

Another anti-Chinese measure that originated with some regional military commanders was the closing of all Chinese-language schools to Indonesian citizens at the end of 1957. This reduced the number of Chinese-language schools from 1800 to about 500. This measure also closed a few Dutch schools, but, again, it was really about Chinese. In this case, the primary reaction to these measures was flight - an exodus of some 120,000 persons, mostly to China. China actually sent ships to pick up the emigrants, many of whom had previously desired to leave Indonesia, but could not pay for the trip. About one-third of these emigrants were young people, mostly from Chinese-language schools, hoping to continue their studies in China. Anny Tan of Retour Amoy ${ }^{17}$ and her family were among those who departed for China, although she and her husband came from Peranakan families and their children had attended Dutch, not Chinese, schools. Probably several thousand left for Taiwan, Europe, and North America during this crisis, but the numbers are not known.

For those who did not flee, an important reaction to the turmoil was the

15 Muaja (1958?). This date of publication is not given.

16 This final decree was known as PP-10, Peraturan Presiden 10/1959 (Presidential Regulation Number 10 of 1959). See Somers (1965: 194-223). For the discussion of closing Chinese schools and implementing the Dual Citizenship Treaty, see also that source and Mozingo 1976.

17 Blussé 2000. 
implementation of the Dual Nationality Treaty with China in 1959-1961. This allowed persons with both Indonesian and Chinese citizenship to choose which one they wanted to keep. Supposedly this "act of choosing" ended the uncertainty of the citizenship status of Chinese Indonesians - but it applied only to those who were Indonesian citizens. Even though a great majority of those eligible chose Indonesian citizenship over citizenship of China, most Chinese in Indonesia could not choose and continued to be aliens.

Finally, in 1963, a minor traffic dispute set off anti-Chinese violence in Bandung and several neighboring cities. The deeper cause may have been a protest against Soekarno's politics and his friendship with China. Again, violence led to emigration. A striking example is Yap Tjwan Bing, who had helped design Indonesian independence in 1945 and who was a loyal adherent of the Nationalist Party. Yap, who lived in Bandung, saw his property sacked and his family physically threated. To protect and support his disabled son, he reluctantly decided to leave temporarily for California, but his exile became permanent. ${ }^{18}$

\section{5-1998: VIOLENCE AND ERASURE}

The 50th anniversary of the September 30, 1965 incident has recalled the mass murders following General Suharto's takeover of power. Anti-Chinese violence and anti-Chinese propaganda, as well as heritage erasure followed. It must be emphasized however that most victims of the violence of 1965-1967 were Javanese and Balinese who were associated with the PKI (Partai Komunis Indonesia, Indonesian Communist Party) - 500,000 or many more were killed, while several times that number were arrested, exiled, and deprived of their civil rights. Among the victims were Chinese, but in general they were not the primary target. However, because the People's Republic of China was blamed for inciting the PKI to rebel, everything Chinese became suspect and many Chinese Indonesians lived in fear.

The military did carry out forced expulsions of Chinese from Aceh, West Kalimantan, and parts of East Java, causing some thousands of deaths. All of this was supposedly to enforce the old bans on alien trade and residence in rural areas. ${ }^{19}$ A recent study has called the Aceh expulsions a "genocide" of the Chinese..$^{20}$ I have not had access to the full study and will reserve judgment here.

In the following years of Suharto's rule, heritage erasure, something the Ranjang Hujan symbolically depicts, meant that all Chinese-language schools were closed, as were nearly all Chinese-language newspapers, even the Chinese temples were Indonesianized, being forced to emphasize their Buddhist tradition and even call themselves "vihara". Import of Chineselanguage texts was equally forbidden. ${ }^{21}$

$18 \quad$ Yap Tjwan Bing 1988.

19 The best, and most reliable, source on these measures is Coppel 1983.

20 Melvin 2013, 2015.

21 The measures had limited success: clandestine instruction in Chinese continued and some 
Again, people left. Chinese Indonesians departed because of physical or psychological threats, bureaucratic harassment and reduced opportunity for educating their children. From the late 1950s, admission of Chinese Indonesians to public universities, especially to popular faculties like medicine and law, was limited. Private universities were expensive and/or not accredited. After 1965, the turmoil was frightening. The economic situation had gone rapidly downhill for years. From 1966, all Chinese were called not the polite "Tionghoa" but the offensive "Cina". Ang Jan Goan, long-time publisher of the newspaper $\operatorname{Sin} P o$, who had consciously chosen Indonesian citizenship in 1960, speaks in his memoirs of "tahun-tahun yang mengerikan" (horrifying years). When in 1968 friends told him of the (false) rumor that he had been arrested, he and his wife decided to join their son in Canada. ${ }^{22}$

Another example is a graduate of a Chinese-language school (before they were closed) who could not enter a public university, studying instead at a private institution. Although he avidly supported the students' protests that led to the fall of Suharto, he still remembers a truckful of young demonstrators that passed him on the street in Jakarta, yelling "Cina pulang" and spitting at him. He too left for Canada, joining an uncle there and continuing his studies. ${ }^{23}$

During the 1960s, Western countries began to open immigration to Chinese. The US and Canada actively recruited doctors until 1968 by admitting people who passed a special test that gave them a right to immigrate. A look at some autobiographies of Chinese-Indonesian doctors who left for North America during the 1960s confirms the motivations listed above. These men left to get ahead professionally, because they were not admitted to specialty training (even though many had served the government for years in remote areas), they sought a better future for their children, and, additionally, they experienced fear of violence and disorder. ${ }^{24}$

Still, the Suharto era was not only negative for the Chinese minority. In the 1980s, nearly all Chinese in Indonesia became citizens, ending - theoretically - the question of their legal status. Political stability, despite repression, and economic growth lifted general welfare. At least one person I spoke with during those years insisted, "as long as the economy is good, Indonesians will be satisfied and we (Chinese) will have nothing to fear". Some Chinese businessmen profited from the new economy - the cukong - by forming close ties to political-military power holders. Restrictions persisted, however. For example, most Chinese Indonesians had to replace their Chinese names with Indonesian-sounding ones, but their identity papers still contained a mark indicating that they were of Chinese origin. ${ }^{25}$

Chinese texts circulated from hand to hand. Similarly, even the famous Tjap Go Meh processions after Chinese New Year, which were not to take place in public, returned in a few places.

22 Ang Jan Goan (2009: 368).

23 Wu Da Ying 2013.

24 Oei Tjien 2009.

25 For an overview of the situation in the Suharto years, see Heidhues 2006. 


\section{SUHARTO'S RULE ENDS IN VIOLENCE}

The run up to the end of President Suharto's New Order government may have started when riots broke out in Medan in 1994. There, workers staged a protest against poor working conditions, but the demonstrations ended with plundering and destruction of Chinese property. Anti-Chinese outbreaks followed in several places in Java, Makassar, Banjarmasin, and again in Medan in the years 1996-1999. Often the spark that lit the explosions had little or nothing to do with Chinese Indonesians, but ended in torching of supermarkets, shops, cars, and houses that belonged to them. Some of the trouble came from conservative Islamic elements reacting against their own lack of power and privilege in Indonesian society.

Unquestionably, especially after the Asian monetary crisis of 1997, the government contributed to anti-Chinese sentiment by harping on the "kesenjangan" (gap) between rich (meaning "Chinese" without distinction between wealthy and not) and poor (meaning "native" - ironically some of whom, especially Suharto's own family, were themselves profiteers). When violence broke out, those in authority often excused the outbreaks by referring to the wealth gap and blaming Chinese for the monetary crisis. In some cases, scores of young men on motorcycles provoked violence and arson. Those who might have suppressed the violence and protected the innocent stood aside. ${ }^{26}$

In May 1998, after four students were shot in Jakarta during non-violent protests against Suharto's rule, there, in Solo, and elsewhere, vicious, coordinated attacks on Chinese property and persons, including rape and sexual humiliation of Chinese women, followed. Perpetrators included truckloads of young, athletic, black-booted men, typical of the paramilitary organizations controlled and manipulated by certain army leaders. They encouraged city people to enter and loot shops and malls, then set fire to the buildings. Of over 1000 dead, most were actually looters, not Chinese, but this does not change the fact that atrocities and violence were directed first at Chinese Indonesians.

Many of them, as well as many foreigners - some estimate the total number to be as much as 150,000 - fled Java for safety in Singapore, Hong Kong, Malaysia, or Australia, or even Bali or West Kalimantan. Probably, most refugees returned to their homes when the political situation became quiet. Vice-President Habibie, who succeeded Suharto, left the task of investigating the outbreaks to official and NGO-initiatives, who produced a lengthy report, but few if any perpetrators were called to account.

Relief came with the subsequent presidencies of Gus Dur and Megawati, who rolled back most anti-Chinese administrative measures, opening the door wide for Chinese culture and Chinese festivities, removing stigmatization of ethnic Chinese, and probably improving the general atmosphere. Bureaucratic harassment has since been reduced, if not eliminated. Serious interethnic violence, often along religious lines, plagued these presidencies, but most was not directed to Chinese as such.

26 This and the following description is based largely on Purdey 2006. 


\section{ViOLENCE IN PERSPECTIVE}

Perhaps it is not correct to discuss violence against ethnic Chinese in isolation. Violence punctuates Indonesian history. ${ }^{27}$ As mentioned, the Revolution was violent and the total number of casualties is unknown. Many of the following years were marked by violence, not only that against the Chinese minority - Darul Islam and regional rebellions come to mind, and more recently the situation in Aceh and Papua. Elements of the military and certain Islamic groups have been repositories of violence, as have, as John Sidel ${ }^{28}$ notes, the kampung people, who may be quick to join when trouble breaks out. For this reason, a potential for anti-Chinese violence remains, and some regions are more susceptible to outbreaks than others. Violence often occurs at times of political transition, when competition for power breaks out in uncertain circumstances, as in the major cases listed above. There is reason for cautious optimism.

Responses from Chinese Indonesians to the changes since 1998 have included modest participation in political life (Jakarta, West Kalimantan), although entry into political competition can also provoke resentment. Chinese Indonesians may now emphasize their rootedness in Indonesia, particularly as Peranakans. They are a suku, and thus pribumi, and their efforts, individual and collective, have contributed to building modern Indonesia. ${ }^{29}$ In 2006, Indonesian President Susilo Bambang Yudhojono helped dedicate a new site at the tourist attraction Taman Mini Indonesia Indah, the Taman Budaya Tionghoa (Garden of Chinese Culture). Some of the discussion surrounding this exhibit involved the question of what is meant by "Chinese" and "Chinese culture". Is the new openness an opportunity to recall the culture of the Chinese mainland in language and architecture or should it emphasize how Chinese culture has been expressed within Indonesia, for example, in Chinese-Malay literature, Peranakan clothing styles, or in the contributions of individuals to public life? ${ }^{30}$

A positive result of the discussion since 2014 is the opening of the Hakka Museum on the Taman Mini site. In that museum, the Wall of Prominent Chinese Indonesians (including many non-Hakkas) displays the moving inscription "Indonesia, we are loyal/ devoted to you!"

\section{REFERENCES}

Ang Jan Goan. 2009. Memoir Ang Yan Goan, 1894-1984. Jakarta: Yayasan Nabil. Blussé, Leonard. 2000. Retour Amoy; Anny Tan - een vrouwenleven in Indonesië, Nederland en China. Amsterdam: Uitgeverij Balans.

Coppel, Charles A. 1983. Indonesian Chinese in crisis. Kuala Lumpur: Oxford University Press.

\footnotetext{
27 Coppel 2006.

28 Sidel 2006.

29 A new three-volume publication has enumerated many such contributions, see Suryadinata and Kwartanada 2016.

30 Eifert (2012: 137-138).
} 
Coppel, Charles A. 2006. "Violence; Analysis, representation and resolution”, in: Charles A. Coppel (ed.), Violent conflicts in Indonesia; Analysis, representation, resolution, pp. 3-18. Abingdon: Routledge.

Cribb, Robert. 2008. "The brief genocide of Eurasians in Indonesia, 1945/46", in: A. Dirk Moses (ed.), Empire, colony, genocide; Conquest, occupation, and subaltern resistance in world history, pp. 424-439. New York: Berghahn Books.

Eifert, Yvonne. 2012. Conflict formation and transformation in Indonesia; Chinese and indigenous Indonesians on their way to peace? PhD thesis, Justus-LiebigUniversität Gießen.

"Guide to the Niels A. Douwes Dekker Papers", Collection Number: 3480, Division of Rare and Manuscript Collections, Cornell University Library, (http:/ /rmc.library.cornell.edu/ EAD/htmldocs/RMM03480.html).

Heidhues, Mary Somers. 2006. “Indonesia”, in: Lynn Pan (ed.), The Encyclopedia of the Chinese Overseas, pp. 151-168. Second Edition. Singapore: Chinese Heritage Centre and Didier Millet.

Heidhues, Mary Somers. 2012. "Anti-Chinese violence in Java during the Indonesian Revolution, 1945-49", Journal of Genocide Research 14: 3-4, 381-401.

Melvin, Jess. 2013. “Why not genocide? Anti-Chinese violence in Aceh, 196566", Journal of Current Southeast Asian Affairs 32: 3, 63-91.

Melvin, Jess. 2015. “Documenting genocide", Inside Indonesia 122 (Oct-Dec). [Retrieved from: http://www.insideindonesia.org/documentinggenocide, accessed March 14, 2016].

Mozingo, David. 1976. Chinese policy toward Indonesia, 1949-1967. Ithaca, NY: Cornell University Press.

Muaja, A.J. 1958. The Chinese problem. Jakarta: New Nusantara.

Oei Tjien. 2009. Memoirs of Indonesian doctors [1 and 2]. Bloomington, IN: Xlibris. [Ebook.]

Purdey, Jemma. 2006. Anti-Chinese violence in Indonesia, 1996-1999. Singapore: Singapore University Press.

Salmon, Claudine and Anthony Siu (eds). 1997. Chinese epigraphic materials in Indonesia; Volume 2: Java. Singapore: South Seas Society.

Siauw Giok Tjhan. 1981. Lima jaman; Perwujudan integrasi wajar. Jakarta/ Amsterdam: Yayasan Teratai.

Sidel, John T. 2006. Riots, pogroms, jihad; Religious violence in Indonesia. Ithaca, NY: Cornell University Press.

Smith, Philip. 2015. "Writing in the rain; Erasure, trauma, and Chinese Indonesian identity in the recent work of FX Harsono", Journal of Southeast Asian Studies 46: 1, 119-133. [DOI:10.1017/S0022463414000642.]

Somers, Mary F.A. 1965. Peranakan Chinese politics in Indonesia. PhD thesis, Cornell University.

Suryadinata, Leo and Didi Kwartanada (eds). 2016. Tionghoa dalam keindonesiaan; Peran dan kontribusi bagi pembangunan bangsa. Jakarta: Yayasan Nabil.

Steedly, Mary Margaret. 2013. Rifle reports; A story of Indonesian independence. Berkeley: University of California Press. 
Tjamboek Berdoeri [pseud., Kwee Thiam Tjing]. 2004. Indonesia dalem api dan bara. Edited by Benedict Anderson. Jakarta: Elkasa. [Original manuscript 1947.]

Twang Peck Yang. 1998. The Chinese business élite in Indonesia and the transition to independence, 1940-1950. Kuala Lumpur: Oxford University Press.

Veer, A.L. van der. 2013. “The Pao An Tui in Medan; A Chinese security force in Dutch occupied Indonesia, 1945-48". [MA thesis, Utrecht University.]

Wu Da Ying [Ngo That Tjien]. 2013. Chinese-Indonesian; An Odyssey through racism, ethnicity and science. Irvine, CA: privately published.

Yap Tjwan Bing. 1988. Meretas jalan kemerdekaan; Otobiografi seorang pejuang kemerdekaan. Jakarta: Gramedia. 